\title{
Developing L2 Learners Metacognitive Strategies through Reading Group Activities
}

\author{
Hellien J. Loppies \\ hellien.loppies@fkip.unpatti.ac.id \\ English Education Study Program, UNPATTI \\ Jeny Lekatompessy \\ jeny.lekatompessy@fkip.unpatti.ac.id \\ English Education Study Program, FKIP UNPATTI
}

\begin{abstract}
The trend of teaching reading comprehension has shifted the gear from cognitive development to metacognitive orientation and Reading Group activity is one way to foster knowledge constructions and meaning-making in the scheme of metacognition. Reviewing the theoretical foundations of reading group activities, this article theoretically addresses how a reading group can promote individual L2 readers' metacognitive reading strategies. This article emphasizes the importance of implementing a reading group to support second language readers to self-regulate their metacognitive reading strategies by planning, monitoring, and evaluating an academic reading text. Further, this article elaborates on adapting principles in setting up reading group activities, based on the authors' L2 teaching practices. Finally, recommendations and directions for future studies are also provided.
\end{abstract}

Key Words: Metacognitive Reading, Strategy, Reading Group

\section{Introduction}

Reading in groups is believed to be beneficial for developing individual student's metacognitive reading strategies. When reading in groups, students develop their 'internalization of social interaction' (Presley et al., 1992). In interacting, they remediate the meaning of a written text, and therefore, they are given the opportunities to take the role to develop strategic independence (Seravallo, 2010). In academic reading, reading group activities have been long applied to employ metacognitive strategy practices. However, to effectively implement and scaffold individuals' use of metacognitive strategies, it is important to elaborate more on why and how reading groups can be applied in L2 classrooms, especially for academic reading.

This article describes how reading group activities can foster metacognitive strategic development. In the next sections, we explain the theoretical foundations of a reading group and 
metacognitive reading strategy. Then, we provide several principles as a reflection of implementing academic reading group activities.

\section{Literature Review}

In helping students applying the reading strategies, Tregaskes and Daines (1989) emphasize that teachers should make "... students aware of their own learning processes' (p.53). In this way, Phakiti (2008) conceptualizes metacognition as a deliberate analysis of how a reader engages with a text by planning, evaluating, and monitoring. Tregaskes and Daines (1989) further point out that the metacognitive reading strategy can be facilitated if a reader can resolve how he/she grasps meaning, associates ideas provide a reason, and concludes to retain the information from a reading text. This means that metacognitive strategies can be made possible by raising students' awareness of their own thinking processes (Yuksel and Yuksel, 2011).

The need to promote metacognitive reading strategy is based on the fact that learning requires learners to change their perspective from what Barahal (2008) explains as '...shifted in thinking about thinking and became more aware of the importance of deep thinking' (p.298). Barahal further argues that teachers always want their students to think critically, but they sometimes cannot identify their students' thinking process since "thinking is invisible" (p.298). In other words, teachers cannot always understand or predict what is in their students' minds during the reading activity. Since thinking skills should be taught and trained by teachers at schools, group work learning activities are highly recommended to facilitate communicative strategies and learning strategies. Fung and Howe (2014) highlight that group work fosters critical thinking skill development that contributes to students' academic achievement when teachers actively and helpfully assist them in responding to a reading text or an oral presentation critically. As a result, there is an urgent need to train teachers to facilitate students to think about thinking in their classroom activities.

For this reason, Seravallo (2010) highlights that reading in a small group is beneficial since the activity is efficient, goal-oriented, and promoting teamwork. Reading in a group is a good idea for managing large classes and to save time rather than individual reading tasks and evaluation. It is also a goal-oriented activity which is not only to develop individual student's reading skills but also to fit in the curriculum issues where both teacher and learners are responsible for deciding learning experiences and learning objectives and determining strategies practice which is beneficial to both learners as a learning group member and learners as an individual (Presley, et al., 1989). Besides, the reading group also promotes teamwork enhancement (Eckel et al., 1999). 
The idea of grouping students, especially in higher-level education, has long been introduced by many universities since the 1990s. Eckel et al. (1999) note that the reading group has been suggested as an effective solution to keep up with the world's transformation and knowledge evolution. When students engage with updated information from their reading, they could increase their knowledge and understanding about what is happening in the current time. Also, both learners and teachers will engage in dialogic interaction, which is claimed as a better insight to provide more opportunities for ideas sharing and investigating (Applebee et al., 2003). Reading teachers can assist the students in perceiving and filtering the information and discussing it with the student.

According to Eckel, Kezar, and Lieberman (1999), the reading group is essential and has answered the emergent higher education problems when dealing with innovations to teaching and learning requirements. This contention is basically poked around the idea that by sharing knowledge in groups, different parties are engaged within a specific topic to deeply analyze, share, and most importantly, solve problems. Maine and Hoffman (2016) call attention to reading group activities to promote joint construction of meaning-making in extracting information from a reading text. They noted that different studies had been conducted to analyze the correlation between reading groups' activity towards either ...' expressive or critical-analytical stances' (p. 46). The result suggests reading group as an applicable involvement of both teacher and students discussions, which have been the basics for individual reasoning for a latter decision to use metacognitive reading strategy.

\section{Discussion}

Related to the above-mentioned consideration and our experiences in researching metacognitive reading strategies, we propose several adapting principles of reading group activities in L2 contexts, promoting the development of metacognitive reading strategies.

Principle 1. Provide opportunities for self-regulated learning experiences. The first thing to consider in raising students' awareness about their own ways of thinking is by giving them chances to propose their own learning experiences. Many studies confirm that L2 readers are less aware of what reading strategies they need to employ when dealing with reading texts in the target language (Hong-Nam, 2014; Jou, 2015). Kuhn (2000) and Sheorey and Mokhtary (2001) contend that $\mathrm{L} 2$ readers often reflect on what comes to their mind before, during, and after reading. This is useful to utilize a metacognitive reading strategy where the planning phase or before reading activity is scaffolded through self-regulated learning. 
Principle 2. Encourage systematic reflection points. Many reading group activities adapted to the higher education learning system have focused on the benefits of knowledge construction and community support (Eckel. et al., 1999; Fung and Howe, 2014). With the L2 learners, a pivotal aspect to think about is to encourage reflection towards a reading text and the strategy that they employ during reading. Based on our experience of implementing reading group activity, we designed a reading template where students have rooms to reflect on their initial reaction to the content they are reading and possible questions raised towards the given text.

Principle 3. Promote the integration of academic literacy (read to write). It is also important to note that $\mathrm{L} 2$ readers should expand their academic literacy skills in the target language. By having them read and discuss in groups, students are scaffolded to conceptualize knowledge and construct meanings. This will, then, possibly benefit when they internalize their reading purposes (after the reading phase) to other aspects of academic literacy skill development, including writing. Maine and Hoffman (2015) highlight this as the phase of '...expressive or critical-analytical stances' (p. 46). With this phase, what we do with our reading group activity is having the students write 2 paragraph-summary and outline the key conclusion of a text.

Principle 4. Stimulate the concept of deep thinking. Teaching students to think about their own thinking has been argued to be difficult (Barahal, 2008). Nevertheless, learning in groups can activate thinking about one's own thinking. This could be made visible by having students discuss in their reading group how their background knowledge or experience about a given topic is correlated to a reading text. Furthermore, when reading and discussing their points of view in a group, students are given opportunities to consider the similarities and differences of their point of view (Presley et al., 1992; Presley and Gaskins, 2006). This will allow the development of critical thinking. Moreover, encouraging students to raise questions about reading text gaps is also crucial in stimulating conscious thinking about employed reading strategies.

Principle 5. Advocate the importance of strategic independence. Another influential aspect of strategy training is to let the individual uses the strategies independently. Seravallo (2010) highlights that reading group activities facilitate strategic independence by promoting focus discussion in which learners take the role of either a facilitator or a reader in a reading group. To provide an example from our class, students are assigned weekly as facilitators and readers. A facilitator is responsible for planning the reading group activities, including choosing an article or chapter of a book and lead the discussion of a given weekly topic. Both member and facilitator are responsible to individually fill in a reading template which questions and requires reflection of individual metacognitive reading approach. By having students read individually and fill in the 
reading template, it is hoped that students can independently and consciously use such strategies in dealing with an academic text in the future.

Table 1. Sample Reading Template

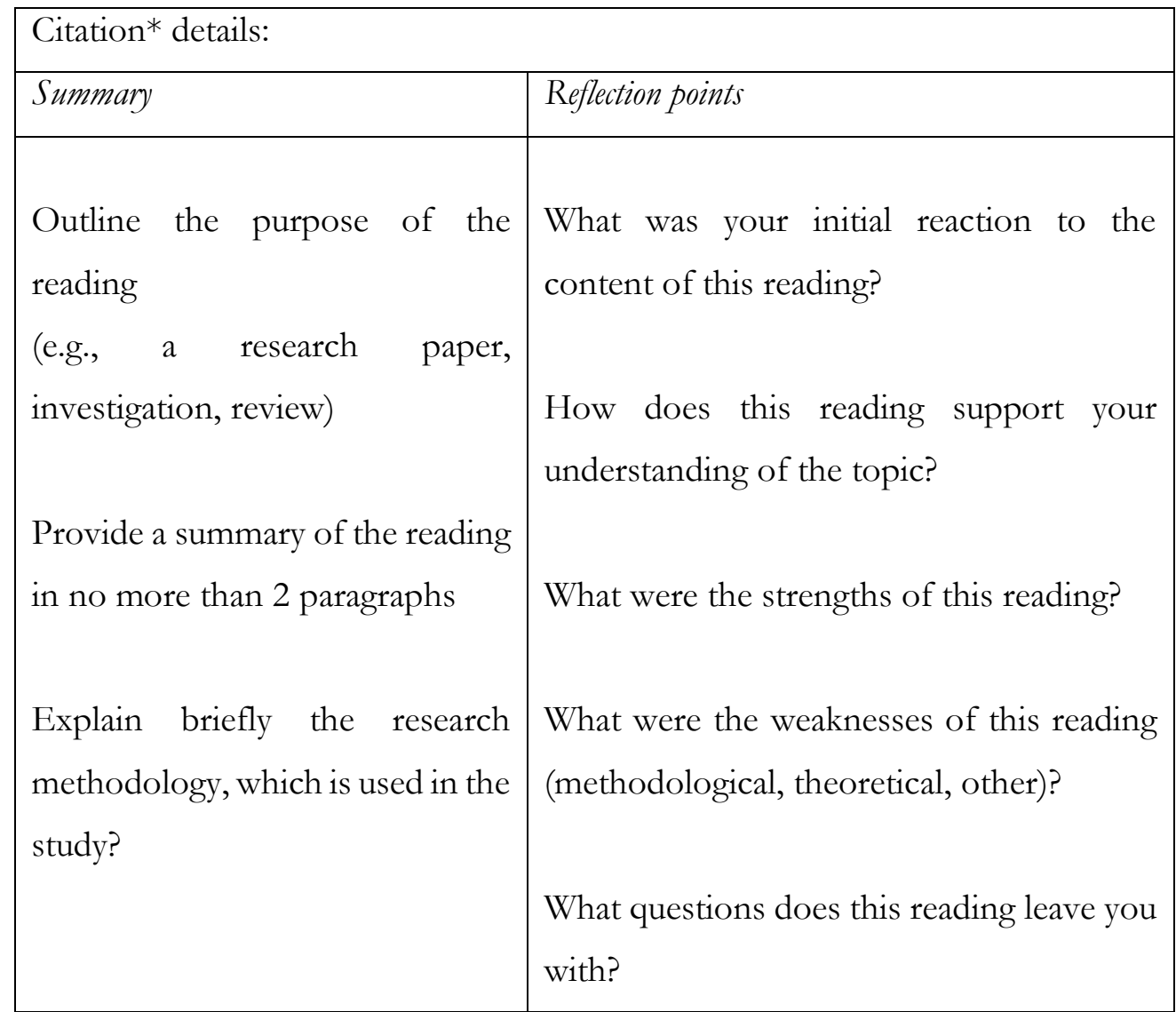

\section{Conclusion}

This paper has elaborated on the benefits of reading group activities by promoting metacognitive strategy when a reader approaches an academic text. These employed strategies emphasize planning, monitoring, and evaluating. In particular, we have reviewed studies and the underpinning theories in implementing reading groups in the context of L2 readers. Based on this study's findings, we recommend five adopting principles that may be considered when designing reading group activities for $\mathrm{L} 2$ readers. These proposed principles accentuate the need to promote self-regulate, critical thinking, academic literacy, and independent strategy, useful for before, during, and after reading phases.

Some issues have been raised from the explanation that needs to be explored in detail. Therefore, it is suggested that future studies can draw closer inquiries to the following areas: 
1. A quantitative study to figure out how reading group activity affects L2 readers' individual metacognitive reading strategy

2. A study to analyze how the proposed principles can be put into action in real classrooms and what challenges teachers and students face in L2 learning contexts.

3. A study to deeply investigate individual L2 reader's progress in employing metacognitive reading strategy independently.

Finally, this paper has argued that some advantages can be utilized by implementing reading group activities to enhance L2 readers' metacognition and promote knowledge construction and meaning-making in general. Therefore, it is hoped that more future studies will focus on reading group activity and metacognitive strategy.

\section{References}

Applebee, A. N., Langer, J. A., Nystrand, M., \& Gamoran, A. (2003). Discussion-Based Approaches to Developing Understanding: Classroom Instruction and Student Performance in Middle and High School English. In American Educational Research Journal. https://doi.org/10.3102/00028312040003685

Barahal, S. L. (2008). Thinking about Thinking. Phi Delta Kappan, 90(4), 298 - 302. https://doi.org/10.1177/003172170809000412

Chevalier, T. M., Parrila, R., Ritchie, K. C., \& Deacon, S. H. (2017). The Role of Metacognitive Reading Strategies, Metacognitive Study and Learning Strategies, and Behavioral Study and Learning Strategies in Predicting Academic Success in Students With and Without a History of Reading Difficulties. Journal of Learning Disabilities. https://doi.org/10.1177/0022219415588850

Eckel, P. D., Kezar, A., \& Lieberman, D. (1999). Learning for Organizing: Institutional Reading Groups as a Strategy for Change. AAHE Bulletin, 6-8. https://repository.upenn.edu/gse pubs/459

Feller, D. P., Kopatich, R. D., Lech, I., \& Higgs, K. (2020). Exploring Reading Strategy Use in Native and L2 Readers. Discourse Processes, 57(7), 590-608. https://doi.org/10.1080/0163853X.2020.1735282

Fung, D., \& Howe, C. (2014). Group work and the learning of critical thinking in the Hong Kong secondary liberal studies curriculum. Cambridge Journal of Education. https://doi.org/10.1080/0305764X.2014.897685 
Hollenbeck, A. F., \& Kalchman, M. (2013). Professional development for conceptual change: Extending the paradigm to teaching reading comprehension in US schools. Professional Development in Education. https://doi.org/10.1080/19415257.2012.728535

Hong-Nam, K. (2014). ELL High School Students' Metacognitive Awareness of Reading Strategy Use and Reading Proficiency. TESL-EJ.

Jou, Y. J. (2015). Investigation of technological university students' use of Metacognitive reading strategies in first and second languages. English Language Teaching, 8(1). https://doi.org/10.5539/elt.v8n1p180

Karimi, M. N., \& Shabani, M. B. (2013). Comparing the strategic behavior of more successful vs. less successful readers of multiple technical reading texts. Innovation in Language Learning and Teaching. https://doi.org/10.1080/17501229.2012.726223

Kuhn, D. (2000). Metacognitive Development. Current Directions in Psychological Science, 9(5), 178181. https://doi.org/10.1111/1467-8721.00088

Maine, F., \& Hofmann, R. (2016). Talking for meaning: The dialogic engagement of teachers and children in a small group reading context. International Journal of Educational Research. https://doi.org/10.1016/j.ijer.2015.10.007

Nash-Ditzel, S. (2010). Metacognitive reading strategies can improve self-regulation. Journal of College Reading and Learning. https://doi.org/10.1080/10790195.2010.10850330

Pammu, A., Amir, Z., \& Maasum, T. N. R. T. M. (2014). Metacognitive Reading Strategies of Less Proficient Tertiary Learners: A Case Study of EFL Learners at a Public University in Makassar, Indonesia. Procedia - Social and Behavioral Sciences. https://doi.org/10.1016/j.sbspro.2014.02.049

Phakiti, A. (2008). Construct validation of Bachman and Palmer's (1996) strategic competence model over time in EFL reading tests. Language Testing. https://doi.org/10.1177/0265532207086783

Pressley, M., \& Gaskins, I. W. (2006). Metacognitively competent reading comprehension is constructively responsive reading: How can such reading be developed in students? Metacognition and Learning. https://doi.org/10.1007/s11409-006-7263-7

Pressley, M., Borkwski, J. G., \& Schneider, W. (1989). Good information processing: What it is and how education can promote it. International Journal of Educational Research. https://doi.org/10.1016/0883-0355(89)90069-4 
Pressley, M., El-Dinary, P. B., Gaskins, I., Schuder, T., Bergman, J. L., Almasi, J., \& Brown, R. (1992). Beyond Direct Explanation: Transactional Instruction of Reading Comprehension Strategies. The Elementary School Journal, 92(5), 513-555. https://doi.org/10.1086/461705

Serravallo, J. (2010). Teaching Reading in Small Groups retrieved from http://www.heinemann.com/products/E02680.aspx

Sheorey, R., \& Mokhtari, K. (2001). Differences in the metacognitive awareness of reading strategies among native and non-native readers. System. https://doi.org/10.1016/S0346251X(01)00039-2

Tregaskes, M. R., \& Daines, D. (1989). Effects of metacognitive strategies on reading comprehension. Reading Research and Instruction, 29(1), 52-60. https://doi.org/10.1080/19388078909557996

Yüksel, I., \& Yüksel, I. (2012). Metacognitive awareness of academic reading strategies. Procedia Social and Behavioral Sciences. https://doi.org/10.1016/j.sbspro.2011.12.164

Zhang, L. (2018). Metacognitive and Cognitive Strategy Use in Reading Comprehension. In Metacognitive and Cognitive Strategy Use in Reading Comprehension. https://doi.org/10.1007/978$\underline{\text { 981-10-6325-1 }}$ 